\title{
Deregulation, Ownership and Profit Performance of Banks: Evidence from India
}

\author{
Rudra Sensarma
}

E-mail: rssensarma@gmail.com

\begin{abstract}
This paper studies the effects of deregulation on the banking industry in an emerging economy using profit-based measures of performance. Using panel data of 83 Indian banks belonging to different ownership groups for the period 1986 to 2005, we find that profit efficiency and productivity declined following deregulation. While public sector banks performed better than private banks in the pre-deregulation period, there was no difference in their performances after deregulation. Foreign and new private banks turned out to have the highest levels of profit productivity. Our results are in contrast with the findings of previous studies that have found significant improvements in efficiency and productivity of Indian banks using cost-based measures of performance.
\end{abstract}




\section{Introduction}

The banking industry, in many economies, has witnessed substantial deregulation from government control especially during the eighties. The impact of deregulation on the performance of banks has been widely studied. ${ }^{1}$ However the evidence emerging from a variety of such studies is mixed. For the USA, it has been found that after deregulation, although cost productivity declined, profit productivity increased as a result of improvement in the quality of output (Humphrey and Pulley, 1997; Berger and Mester, 2003). For some other countries, deregulation was not necessarily associated with improvement in efficiency and productivity, e.g. Spain (Lozano-Vivas, 1998; Kumbhakar et al., 2001) and Portugal (Mendes and Rebelo, 1999). On the other hand, banking sector reforms yielded positive results in Norway (Berg et al., 1993), Taiwan (Chen, 2001), Korea (Gilbert and Wilson, 1998) etc.

Most of the existing studies pertain to developed economies and evidence for developing economies is few and far between. The few studies that exist for developing economies have mostly concentrated on estimating either technical efficiency or total factor productivity (TFP) or cost efficiency of banks, based on their production or cost functions. In the banking literature it is increasingly being argued that profit maximization under certain circumstances may be a better specification than cost minimization (Berger and Mester, 2003). Banks may undertake costly ventures in order to benefit in terms of profits. Cost measures may identify such banks as inefficient whereas profit measures may term them as good performers. Accordingly in this paper we assess the performance of Indian banks in terms of profit efficiency and profit productivity, and examine the effects of deregulation on performance. 
Among the few studies that have analyzed bank performance in India, our results are compared and contrasted specifically with two papers. Kumbhakar and Sarkar (2003a), employing a generalized shadow cost function approach with data for the period 1986 to 1997, found that TFP of Indian banks has increased subsequent to deregulation. Kumbhakar and Sarkar (2003b), using the technique of stochastic frontier analysis with data for the period 1986 to 2000, observed a rise in cost efficiency. Both these studies found that private banks performed better than the state owned public banks. It would be instructive to complement these results by studying profit performance of Indian banks during this period. The present paper seeks to provide evidence in this direction with an updated data set.

There are some other studies of bank performance in the Indian context, but either their data period is insufficient to study the full impact of deregulation which was initiated in $1992^{2}$ or the econometric methodology does not adequately measure performance. ${ }^{3}$ More recently, Shanmugam and Das (2004) used a larger data set to estimate efficiency of Indian banks using various stochastic frontiers. But they too did not study profit performance of banks.

In this paper, based on data for the period 1986 to 2005 , our main finding is that performance of Indian banks has declined in terms of profit productivity. This result is in contrast with findings from developed economies. For instance, in the case of USA it has been observed that cost productivity declined and profit productivity improved during the period of deregulation (Berger and Mester, 2003). We argue that in the case of a developed economy, the markets and business models were already in an advanced state of maturity and development. Hence deregulation of controls unleashed the existing 
potential in banks to innovate, invest in new technology and offer services of superior quality, thereby improving their profit performance while suffering losses on the cost side due to the additional operating expenditure incurred. However in the case of a developing economy such as India, we expect that deregulation (characterized by freeing up of controls on pricing, expansion, entry etc.) would result in lowering of costs due to adoption of efficient technology but also put a pressure on profits due to the intensification of competition. ${ }^{4}$ Our findings are in line with this expectation.

The rest of the paper is organized as follows. Section 2 provides an overview of regulatory changes in Indian banking. Section 3 discusses the stochastic frontier methodology we employ. Section 4 presents the data used in the paper and formalizes the econometric specification. Section 5 and Section 6 are devoted to discussions of the results from the analysis of efficiency and productivity, respectively. Section 7 presents a comparison of our profit based results with the cost based results available in the literature. Section 8 concludes the paper.

\section{Regulatory Changes in Indian Banking}

Indian banking industry is characterized by the co-existence of state owned public banks, private banks (incumbents and entrants) and foreign banks. Prior to deregulation, Indian banking was a highly controlled industry. The Reserve Bank of India (RBI) initiated banking sector reforms on the recommendations of the Narasimham Committee on Financial Sector Reforms (submitted in 1991). The first set of reforms in 1992-1993 included entry deregulation (leading to entry of new private banks), branch de-licensing and deregulation of interest rates. Public banks were for the first time permitted to raise 
up to $49 \%$ of equity from the capital market thereby encouraging them to become market oriented. Capital adequacy norms of a minimum $8 \%$ Capital to Risk-weighted Assets Ratio (CRAR) were imposed and stringent income recognition and provisioning norms were introduced in 1993. Statutory pre-emptions were reduced in several stages, e.g. the Statutory Liquidity Ratio (SLR) requirement was brought down from $38.5 \%$ in 1991 to $25 \%$ and Cash Reserve Ratio (CRR) requirement from $7.50 \%$ in 1991 to $5 \%$ in 2005.

Subsequently, in the backdrop of the Basel Committee recommendations and the Asian financial crises, the report of the Second Narasimham Committee (submitted in 1998) paved the way for the 'second generation reforms' in the Indian banking industry. The Committee's recommendations led to prudential measures like higher CRAR (9\% with effect from March 31, 2000), allowing for market risk on government securities, stricter Non-Performing Assets (NPAs henceforth) norms, introduction of AssetsLiabilities management and Risk management guidelines. More recent changes in Indian banking include legislation for NPA recovery and setting up of Debt Recovery Tribunals in 2002, introduction of risk based supervision in 2003 and RBI's issuing guidelines for mergers of private banks and identifying a road-map for entry of foreign banks in 2005 .

The banking sector reforms in India, initiated in 1992, freed up the industry from a lot of controls and offered a level playing field to all bank groups. While, the increase in operational freedom is expected to have improved productivity of all bank groups, the intensification of competition could have put pressure on profitability. Therefore it can be expected that even though cost efficiency and productivity of banks would have increased, but bank performance in terms of profit measures may have declined. As regards the relative performance of public and private banks, while private ownership is theoretically 
associated with superior performance, the public banks in India enjoyed state support till the deregulation of the industry. After deregulation, the public banks received less state support but became more market oriented. Hence it is difficult to form a priori expectations about the relative performance of public and private banks. On the other hand, foreign banks with their costly practices may not have been profit efficient but the new private banks that started operations only after deregulation can be expected to have shown high growth.

\section{Econometric Methodology}

The disadvantages of employing standard regression methodology to bank performance studies have been widely documented (see e.g. Berger and Humphrey, 1997). Since banking industry is characterized by a lot of variation, frontier analysis offers a useful way to assess the relative performance of the banks. In this paper, we use the parametric approach of Stochastic Frontier Analysis which allows for error in the data owing to luck, data problems, or other measurement errors. ${ }^{5}$ This technique allows us to examine the performance of individual banks relative to a frontier that is estimated based on the production, cost or profit functions. Banking being a multi-product industry poses difficulties in estimation of a production frontier. Hence we are left with the choice between a cost and a profit frontier.

Berger and Humphrey (1997) noted that the majority of efficiency and productivity studies in banking have focused on the cost function while the revenue side has been relatively less researched. Recent studies in banking have started focusing on profit based approaches (Berger and Mester, 1997, 2003; Williams and Gardener, 2003; 
Maudos and Pastor, 2003; Casu and Girardone, 2004; Pastor and Serrano, 2005). Berger and Mester (2003) argue that profit maximization hypothesis may better describe the economic goals of managers and owners of a bank, who take into account revenues as well as costs while taking decisions. Banks might often want to incur additional expenses, because they want to concentrate on attracting high quality personnel and on making investment in high cost capital, in order to improve the quality of their products and services. Since quality is difficult to measure, failure to account for the quality of output implies that such costs will show up as cost inefficiency. Thus the profit efficiency or productivity of these banks may be higher than the same measures in terms of cost. This is referred to as the 'quality hypothesis' (Berger and Mester, 1997).

It cannot be unambiguously asserted whether Indian banks follow a cost minimization or profit maximization objective and it may be argued that the banking industry has features of both these hypotheses. Subsequent to deregulation, even public banks have become profit conscious as government support through recapitalization has come down considerably and these banks are accessing the capital markets for funds. This necessitates the presence of a healthy balance sheet. Thus public banks are actively competing with their private counterparts in increasing earnings by attracting customers and marketing innovative products, especially in the retail segment. Therefore it would be appropriate to appraise performance of Indian banks under the profit maximization hypothesis.

There are two models of profit function in the banking literature. The standard profit function assumes that banks maximize profit choosing the levels of output, while prices of output and input are given. When it is difficult to estimate the standard profit 
function, researchers take recourse to the alternative profit function (Berger and Mester, 1997; Humphrey and Pulley, 1997) that assumes that banks maximize profit choosing output prices, while output levels are constrained. ${ }^{6}$ It has been widely found that results obtained from alternative profit function are very close to those obtained from standard profit function (Kumbhakar et al., 2001; Berger and Mester, 2003).

We adopt the alternative profit function for the efficiency and productivity analysis in this paper. ${ }^{7}$ Growth in the local economies in India is likely to determine the extent of deposit mobilization or lending by a bank. Hence a bank may face a constraint on the output side as it may not be possible to change its output quickly, either through change in size of the portfolio or number of branches. But there may be some amount of flexibility in choosing output prices resulting from gradual deregulation of interest rates. Banks in India are free to choose all interest rates other than those on saving deposits and small loans. Furthermore, the banking market structure may be characterized neither by full monopoly nor by perfect price competition. This imperfect competition in prices can be best captured by an alternative profit function whereby banks facing an output constraint choose prices to maximize profits. Moreover, the standard profit function requires one to have good data on prices of outputs which is difficult to obtain. To overcome this, often empirical studies use imperfect measures for output prices that can introduce measurement errors in the analysis. In the alternative profit function, prices are choice variables and the profit function depends on output levels which are not only easy to obtain, but also cleanly measured. Based on these reasons, we adopt the alternative profit function to study efficiency and productivity of Indian banks. 
Following the stochastic frontier methodology of Battese and Coelli (1995), the frontier based on the alternative profit function can be specified as follows:

$\pi$ it $=\mathrm{f}\left(\mathrm{Y}_{i t}, \mathrm{~W}_{i t}\right)-\mathrm{U}_{i t}+\mathrm{V}_{i t}----(1)$

where $\pi$ it is profit, $Y$ is the output vector and $W$ is the vector of factor prices (all variables are measured in logarithms); the $V_{i t}$ are random variables which are assumed to be iid $N\left(0, \sigma_{V}^{2}\right)$, and independent of the random variables $U_{i t}$ which account for technical inefficiency and are assumed to be independently distributed as non-negative truncations of the $N\left(\mu\right.$ it, $\left.\sigma_{U}^{2}\right)$ distribution, such that:

$U_{i t}=Z_{i t} \delta+\varepsilon_{i t}$

where, $Z_{i t}$ is an $1 \mathrm{xp}$ vector of variables which may influence inefficiency; $\delta$ is a px1 vector of parameters to be estimated; and $\varepsilon_{i t}$ are random variables, defined by the truncations of $N\left(0, \sigma_{V}^{2}\right)$ such that the point of truncation is $Z_{i t} \delta$. The parameterization from Battese and Corra (1977) is used, replacing $\sigma_{V}^{2}$ and $\sigma_{U}^{2}$ with $\sigma_{S}^{2} \equiv \sigma_{V}^{2}+\sigma_{U}^{2}$ and $\gamma \equiv \sigma_{U}^{2} / \sigma_{S}^{2}$. The $\mathrm{i}^{\text {th }}$ bank's profit efficiency relative to the profit frontier is estimated as $P E_{i t}=\exp \left(-U_{i t}\right)$

\section{Data and Econometric Specification}

For selecting the bank's output vector, we follow the value added approach (Grifell-Tatje and Lovell, 1996; Berg et al., 1993) that treats both deposits and loans as output. ${ }^{8}$ Thus, our output vector consists of value of fixed deposits (FD), saving deposits (SD), current deposits (CD), investments (INV) and loans and advances (ADV). Apart from these, we 
also include the number of branches (B) as an output variable. ${ }^{9}$ This is considered important as the number of branches can proxy for the quality of services (Berg et al., 1993; Kumbhakar et al., 2001). The number of branches also proxies for the size of the bank's transactions which in the absence of data on the number of deposit and loan accounts is a better way of adopting the value added approach (Grifell-Tatje and Lovell; 1996).

Labour $(L)$ and Physical Capital $(K)$ are the two variable inputs. The dependent variable is net profit $(\pi) .{ }^{10}$ Price of labour $\left(w_{L}\right)$ is obtained by dividing total establishment expenses (salaries and benefits) by total number of employees. Price of capital $\left(w_{K}\right)$ is obtained by dividing the total expenditure on physical capital by total fixed assets. All nominal variables are converted to real by measuring them at $1993-94$ prices. The data are taken from various issues of Financial Analysis of Banks and Performance Highlights of Banks published by the Indian Banks' Association. We analyze data on 83 banks for 20 years over the period 1986 to 2005 . In all, there were 27 public banks, 25 domestic private sector banks (private banks, henceforth), 22 foreign banks, and 9 new domestic private sector banks (new private banks, henceforth) in our data set. However, we have an unbalanced panel because not all banks (other than public banks) operated throughout the period and data for some banks were not available in some periods. The minimum number of banks in any year was 16 for private banks (in 2004), 8 for foreign banks (in 1996) and 6 for new private banks (in 2005). This left us with a sample of 1362 observations. New private banks are the only entrants in this study and since they started operating after deregulation, their data were available only from $1996 .{ }^{11}$ Table 1 presents the group-wise means of the key variables used in our study for five different years from 
our data-set. From this table, it is evident that public banks were the most important constituents of the industry although new private banks appear to have expanded quite rapidly after their entry.

We differ from existing studies on Indian banking based on the stochastic frontier approach (e.g. Kumbhakar and Sarkar, 2003a; Kumbhakar and Sarkar, 2003b; Shanmugam and Das, 2004) in several ways. First, we estimate a stochastic profit frontier from which we obtain profit efficiency. Second, we include both foreign and new private (entrants) sector as separate groups in the analysis. This allows us to take a closer look at the comparative role of competition and ownership. Third, we examine the role of size in determining efficiency. Fourth, we consider each category of deposit separately in the output vector. Fifth, we study profit productivity by combining estimates of technical progress and efficiency growth.

Finally it is noteworthy that very few existing studies have attempted to study performance of Indian banking using profit based measures, e.g. Sarkar, Sarkar and Bhaumik (1998); Bhaumik and Dimova (2004) and Koeva (2003). All of these studies have used profitability indicators like return on assets and operating profit ratio as dependent variables in regressions involving a host of explanatory variables and ownership dummies. We have argued earlier that regression analysis is not an appropriate technique in the context of the bank performance. So far as we are aware, this is the first study that uses a stochastic profit frontier to study profit efficiency and profit productivity of Indian banks. 
We adopt the translog form as our specification for (1) since it provides sufficient flexibility to a parametric function while maintaining parsimony of parameters (unlike the fourier flexible function). The translog function in our case takes the following form:

$$
\begin{aligned}
& \ln \pi_{i t}=a_{0}+\sum_{m} a_{m} \ln y_{m i t}+\sum_{j} b_{j} \ln w_{j i t}+b_{t} t \\
& +\frac{1}{2}\left\{\sum_{m} \sum_{l} a_{m l} \ln y_{m i t} \ln y_{l i t}+\sum_{j} \sum_{k} b_{j k} \ln w_{j i t} \ln w_{k i t}+b_{t t} t^{2}\right\} \\
& +\sum_{m} \sum_{l} a_{m j} \ln y_{m i t} \ln w_{j i t}+\sum_{m} a_{m t} \ln y_{m i t} t+\sum_{j} b_{j t} \ln w_{j i t} t+U_{i t}+V_{i t}
\end{aligned}
$$

Following Berger and Mester (2003), we impose parametric restrictions for symmetry $\mathrm{a}_{\mathrm{ml}}=\mathrm{a}_{\mathrm{lm}}$ and $\mathrm{b}_{\mathrm{jk}}=\mathrm{b}_{\mathrm{kj}}$ and linear homogeneity in $\mathrm{w}\left(\sum_{j} \mathrm{~b}_{\mathrm{j}}=1, \sum_{j} \mathrm{~b}_{\mathrm{jk}}=0 \forall \mathrm{k}\right.$, $\left.\sum_{j} a_{m j}=0 \forall m, \sum_{j} b_{j t}=0\right)$. This leads us to normalize profit and input prices by the price of capital before taking logarithms. ${ }^{12}$

Next, to model the inefficiency term, we hypothesize that the determinants of bank inefficiency are deregulation, size and nature of ownership. Hence we have the vector $Z_{i t}^{\prime}=(T$, DEREG, SIZE, PUB, PVT, NEWPVT, Interaction terms $)$, where $\mathrm{T}$ is the trend which accounts for change in inefficiency over time. DEREG is a deregulation dummy taking the value one for years 1993 and above, and zero otherwise. ${ }^{13}$ SIZE is taken to be log of total assets. PUB, PVT and NEWPVT are ownership dummies that take the value one if a bank belongs to the public sector, private sector and new private sector respectively, and zero otherwise. ${ }^{14}$

\section{Profit Efficiency Results}


We first present the estimates of the frontier parameters (see Table 2) and then discuss our results. Since the main focus of the analysis is on inefficiency and its determinants, we do not discuss the estimated coefficients of the profit function. At the outset it is important to verify whether inefficiency effects are at all present or if they have simpler distributions, which would indicate whether the stochastic frontier model framework is necessary for our analysis. We can do this by first performing a composite test of $\gamma=\delta_{0}$ $=\ldots .=\delta_{13}=0$. The test uses a generalized likelihood ratio (LR) which follows a mixed chi-squared distribution (Coelli and Battese, 1996). In our case the null hypothesis is rejected (LR test statistic of the one-sided error is 705.93 which is greater than the appropriate mixed-Chi square statistic available in Table 1 of Kodde and Palm, 1986). Hence simple regression estimation would not be adequate and stochastic frontier estimation is necessary. We also test whether the inefficiency effects have a simpler distribution such as half-normal with zero mean. We can do this by testing for $\delta_{0}=\ldots .=$ $\delta_{13}=0$. Again, a generalized LR test rejects the null hypothesis (LR test statistic is 625.12 which is greater than the appropriate mixed-Chi square statistic available in Table 1 of Kodde and Palm, 1986). Hence our tests suggest that bank specific inefficiency effects are present and that such inefficiencies are better modeled within a stochastic frontier framework.

Moving on to the behavior of inefficiency, we focus on the last three columns of Table 2 which provide the estimated inefficiency model. The coefficient of $\mathrm{T}$ indicates the time behavior of inefficiency prior to deregulation (i.e. when DEREG $=0$ ) and is not significant at the $5 \%$ level. This suggests that profit efficiency of the banking industry did not exhibit any significant trend prior to deregulation. However, to discern the 
movement of profit efficiency over the entire sample period, we estimated a reduced inefficiency model with $\mathrm{T}$ as the only regressor (see Table 3 for the reduced inefficiency models). The positive and significant coefficient of $\mathrm{T}$ in the reduced model suggests that the average profit efficiency of the industry did decline over the entire period. Deregulation did not stop this decline on an average as is indicated by the insignificant coefficient of DEREG*T in a reduced inefficiency model with only $\mathrm{T}$ and DEREG*T as regressors (see Table 3).

Turning to the role of ownership, we see from Table 2 that the coefficients of the public and private dummies, per se, have statistically significant coefficients. Thus, prior to deregulation (i.e. when DEREG $=0$ ), ownership was important in determining profit efficiency. In fact, the relative values of the coefficients of these dummies show that, public and private banks were the most efficient, followed by foreign banks. For the entire sample period, public banks were more profit efficient than private, new private and foreign banks in this order, as shown by the relative values of the coefficients of the ownership dummies in a reduced inefficiency model with only the ownership dummies as regressors (see Table 3).

Having separately studied the roles of deregulation and ownership in affecting profit efficiency, we now analyze the presence of ownership effects in the impact of deregulation on performance. In other words, we investigate whether the impact of deregulation on performance is different across ownership groups. This can be studied in terms of the full model whose estimates are presented in Table 2. We observe that all those terms that contain interaction between deregulation and ownership, viz. DEREG*PUB, DEREG*PVT, DEREG*T*PUB and DEREG*T*PVT, have statistically 
significant coefficients. This indicates the presence of ownership effects in deregulation. The impact of deregulation on profit efficiency of any bank group can be discerned by collecting all the relevant terms involving the DEREG variable. For example, the impact of deregulation on profit efficiency of public banks alone can be derived from the coefficients of DEREG, DEREG*T, DEREG*PUB and DEREG*T*PUB. The marginal impact of deregulation on public banks (i.e. the first derivative of inefficiency with respect to DEREG, such that only PUB $=1$ ) is therefore given by the sum of -0.562 , 0.073 multiplied by $\mathrm{T},-1.571$ multiplied by 1 , and 0.153 multiplied by $\mathrm{T}$ and 1 . This is positive for $\mathrm{T}$ equal to 10 and above ( $\mathrm{T}$ takes the value of 10 in the year 1995), suggesting that subsequent to deregulation, profit efficiency of public banks did decline.

The impact of deregulation on the other groups were similarly calculated, and the results for foreign banks were similar to those for public banks, viz. that profit efficiency declined subsequent to deregulation, but the profit efficiency of private banks increased after deregulation. The next question we turn to is the role of size in efficiency. We observe that the coefficient of the size variable is negative and statistically significant thereby implying that profit efficiency is higher for bigger banks.

Next we estimate bank-wise efficiency for each year. From this, we compute the group-wise efficiency estimates for each year by taking a simple mean over the constituent banks of each group. ${ }^{15}$ These mean efficiencies are reported in Table 4. From the mean values, we notice that in the years prior to 1993, public banks performed better than the public, new private and foreign banks in that order. T-tests of mean differences of the profit efficiencies confirm this finding at $1 \%$ level of significance. ${ }^{16}$ However, subsequent to deregulation, t-tests of mean differences suggest that there was no 
significant difference in the profit efficiency of public and private banks. In other words, private banks took the lead in improving the quality of their services and therefore were able to close their gap in profit efficiency with public banks. Public banks, however also improved their profit efficiency after 2001 which indicates that they were late in picking up the benefits of deregulation. However, public banks had much higher profit efficiency than foreign banks throughout the sample period, as confirmed by t-tests of mean differences in both the sub-periods of pre and post-deregulation.

The above results can be summarized and interpreted as follows. First, the fall in profit efficiency over time suggests that, compared to those banks that comprised the frontier, profits of the other banks declined. This implies that the intensified competition in the banking industry had the expected effect of reducing profits. While some banks comprising the frontier managed to take the lead in delivering innovative products of superior quality as a response to the increasing competition, most banks took time to adjust to the required reorientation in their business. So most banks could not produce the optimal output combination so as to reap maximum profits and hence moved away from the profit frontier. In fact a similar decline in profit efficiency has also been reported in the case of Japanese banks (Maudos and Pastor, 2001) and Spanish banks (Maudos and Pastor, 2003).

Second, while public banks were more profit efficient than private banks prior to deregulation, their difference was insignificant after deregulation. Before the banking sector reforms, public banks were heavily protected by the government whereas the private banks had to face many restrictions in their operations. This may have led the public banks to be more profit efficient than the private banks. However, in the post- 
deregulation regime, a level playing field was created for all bank groups. Private banks were able to improve the quality of their products and services better than the public banks (i.e. the 'quality hypothesis'). Private banks took the lead in investing in a lot of new areas like setting up ALPM (Advanced Ledger Posting Machine) branches, upgradation of technology, flexible banking hours, online banking etc., which earned them higher revenues that more than made up for the additional costs incurred. The response of public banks was delayed, but they did follow up with superior technology and better quality of services as well, which allowed them to maintain high profit efficiency levels, which was in fact much higher than that of foreign banks.

Foreign banks remained the most inefficient group on the profit front. This has also been observed for the transition economies of Central and Eastern Europe where foreign banks were found to be less profit efficient than domestically owned private banks and state-owned banks (Yildirim and Philippatos, 2002). Lower profit efficiency of foreign banks in India may be a reflection of their high cost practices. Foreign banks incur a lot of expenditure on high wages of employees and on costly real estate. Also, practices like offering free remittance facilities to top-end customers or pushing cheap retail loans in order to capture retail markets may have adversely affected their profit efficiency. On the deposit side, foreign banks have higher proportion of fixed deposits as compared with domestic banks. This entails higher interest expenditure due to higher interest rates and leads to lower spreads. Moreover, being unlisted in India and being a small fraction of their parent entities, they may not be under pressure to perform as much as the domestic banks. 
Finally, size appears to positively impact profit efficiency. This suggests that big banks are able to contain costs owing to scale economies and hence exhibit higher profit efficiency. However it may be noted that public banks are generally the bigger banks in India. In fact, the correlation coefficient of PUB and SIZE dummies turned out to be greater than 0.6 in every year, although it has been gradually declining over the years. ${ }^{17}$ Hence it may also be possible that the higher profit efficiency of the public banks is being partly picked up as a size effect. This finding of a positive impact of size on efficiency is different from that of Bhaumik and Dimova (2004) who observed that for Indian banks during the period 1996 to 2001, size seem to have had a negative impact on accounting indicators of performance. Previous studies on profit efficiency provide mixed evidence on the relation between size and efficiency (e.g. while Berger and Mester, 1997 and Williams and Gardener, 2003 find negative relation, Kasman and Yildirim, 2006 find no relation).

So far we have analyzed profit efficiency. However efficiency and productivity are different concepts and a low value of one does not necessarily imply a low value of the other. For example, productivity measured by TFP can be shown to consist of scale effects and technical change effects, in addition to efficiency growth. Hence, a bank with low efficiency could be reaping scale economies or benefiting from technical progress so as to have a high productivity growth. Thus any study of performance would remain incomplete without an analysis of productivity growth. We turn to this issue in the next section.

\section{Profit Productivity Results}


Productivity or TFP of any firm is commonly defined as a measure of output produced relative to input usage. Change in efficiency, as was estimated in the previous section, can be shown to be one of the components of TFP growth. Based on the stochastic frontier (of production, cost or standard profit), Kumbhakar and Lovell (2000) provided a decomposition of TFP growth as the sum of a technical change component, a scale economy component and an efficiency growth component.

However, in the case of the alternative profit specification, scale effects cannot be measured, due to the absence of Shephard-Hotelling derivative properties (Kumbhakar and Lovell, 2000). Thus, a measure of TFP cannot be estimated based on the alternative profit frontier due to absence of the scale component. The components of technical change (capturing shifts in the alternative profit frontier) and efficiency growth can however be estimated from the alternative profit frontier. Thus, based on the estimated alternative profit frontier, we can estimate two out of the three components of TFP growth to arrive at a measure which represents profit productivity.

Such a measure of profit productivity would give us a more comprehensive measure of profit performance of banks than simply profit efficiency. Profit productivity measures how productive a bank is in increasing its profit using the employed resources. The literature provides a variety of similar profit performance measures based on the alternative profit frontier. Humphrey and Pulley (1997) calculated a 'profit index' based on the alternative profit function, as the ratio of current profit to the previous period's profit. Then they decomposed it into effects of 'technical change' (the extent of shift of the alternative profit function) and 'business environment' (exogenous variables specified 
in the alternative profit function). They did not have a profit efficiency component in the 'profit index' since their alternative profit function did not consider an inefficiency term.

Berger and Mester (2003) defined a measure of profit productivity, based on the alternative profit frontier, which reflects the proportional change in profit over time for a given set of 'business conditions' (i.e. exogenous variables specified in the alternative profit frontier). First, they defined change in profit as the product of three components, viz. contributions from change in best practice (or technical change), change in efficiency and change in business environment. Then they defined profit productivity as the product of the first two factors. In logarithm terms, this is the same as defining profit productivity growth as a sum of technical progress and efficiency growth. Kumbhakar et al. (2001) used a profit frontier to estimate productivity growth as "the sum of technical change (shifts in the profit frontier through time, ceteris paribus and change in profit technical efficiency components". Drawing from these studies, in order to study the profit performance of Indian banks, we define profit productivity growth as, $\quad \dot{P} R O D \pi=\dot{\pi}(Y, W, t)-\frac{\partial U}{\partial t} \quad,{ }^{18} \quad$ which $\quad$ is then rewritten as, $\dot{P} R O D \pi=\dot{P} R O D \pi_{1}+\dot{P} R O D \pi_{2}$.

$\dot{P} R O D \pi_{1}$ gives the technical progress component (which shows the extent to which the profit frontier has shifted up, resulting from improved techniques or regulatory

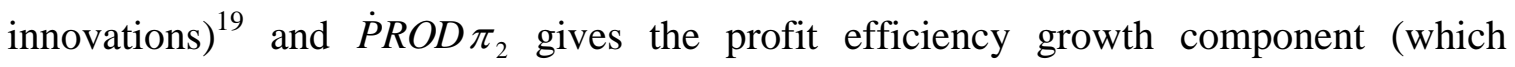
indicates the proximity of banks to the profit frontier) of profit productivity growth. Thus, profit productivity growth estimates the overall profit performance of a bank emanating 
from a shift in the profit frontier as well as a movement towards or away from the profit frontier.

In order to study the behaviour of profit productivity, we construct indices of each component of profit productivity, i.e. $P R O D \pi_{i}(\mathrm{t})=P R O D \pi_{i}(\mathrm{t}-1)\left[1+\dot{P} R O D \pi_{i}(\mathrm{t})\right]$, and it is set at 100 for the initial year. The mean $\dot{P} R O D \pi_{i}$ are calculated for each bank group for each year. Based on these means, $P R O D \pi_{i}$ are computed for each bank group for each year. $P R O D \pi$ is computed in a similar fashion. ${ }^{20}$

Columns 2 to 4 of Table 5 reports the movement of mean $P R O D \pi_{1}$ which gives the technical change component. It is evident that there has been a fall in the technical progress component of profit productivity which is associated with a downward shift in the profit frontier. We have argued earlier that this is expected in an industry moving from a regulated to a deregulated regime where greater intensity of competition would drive down profits. Moreover, entry would further intensify the competition, contributing to the squeeze in profits which once again gets manifested in the technological deterioration of the profit function. In other words, during a process of deregulation, the share of each firm in industry profits declines both because more intense competition leads to lower prices and therefore lower profits and because, subsequent to entry, there are more number of firms to share the total pie.

The higher $P R O D \pi_{1}$ values of public banks suggest that this group did better in arresting the decline compared to foreign and private banks (t-tests of mean differences confirmed this). Although the profit productivity levels for new private banks are not strictly comparable with the other groups (since the initial year for this group is 1996), we can see from Table 6 that $P R O D \pi_{1}$ declined over time even for this group. We also 
recomputed the indices for all bank groups by taking the base at 1996 so that we could get comparable values for all bank groups with new private banks during the period 1996-2005. This showed that the new private banks performed almost similar to the public banks during this period. ${ }^{21}$

Columns 5 to 7 of Table 5 reports the movement of mean $P R O D \pi_{2}$ which gives the efficiency growth component of profit productivity. While the previous section documented the movement of profit efficiency levels, $P R O D \pi_{2}$ represents a productivity index based on the growth of profit efficiency. Note that although efficiency levels of foreign banks were relatively low, in terms of efficiency growth they have been performing better than the other groups. In fact, t-tests of mean differences of the $P R O D \pi_{2}$ values suggested that foreign and private banks have performed better than the public banks in terms of efficiency growth. Therefore foreign banks, in spite of their low profit efficiency levels, appear to be rapidly improving their performance as compared with private and public banks. New private banks, even though not comparable with the other groups in terms of the profit productivity levels, exhibited rapid efficiency growth as well (see Table 6). When we recomputed the indices for all groups taking the base at 1996, new private banks performed the best in terms of efficiency growth.

The $P R O D \pi$ index is reported in columns 8 to 10 of Table 5 . This gives the overall performance of banks in terms of profit productivity. From the reported values, we discern two features. Firstly, profit productivity has fallen over the years for all bank groups. This, as we have already discussed, is expected in a deregulating industry where severe competition from incumbents as well as entrants would lead to a fall in profits. Secondly, foreign banks appear to have performed better than the public and private 
banks in terms of profit productivity. T-tests of mean differences in $P R O D \pi$ indicated that foreign banks performed better than the other groups in both the pre and postderegulation regimes. On the other hand, while public banks had higher profit productivity than the private banks in the pre-deregulation regime, the difference was statistically insignificant in the post-deregulation period.

Foreign banks, through the use of innovative revenue generating strategies, appear to have arrested their decline in profit productivity after deregulation better than the other groups. As in the case of efficiency, private banks were able to close their gap in productivity with public banks by taking advantage of the deregulation process. Although the profit productivity levels of new private banks are non-comparable with the other groups, we observe the same falling trend in $P R O D \pi$ for this group as well (see Table 6). Taking recomputed indices with base year as 1996 for all groups, new private banks turned out to be the best performers.

\section{Comparison of Profit Results with Existing Evidence}

It is useful at this point to compare our results based on the profit function with the existing evidence based on cost function. International evidence gives conflicting conclusions based on a comparison of the cost and profit approaches. To give a few examples, Berger and Mester (2003) report substantial fall in cost productivity but rise in profit productivity for US banks. This is attributed to banks providing additional or higher quality of services that raised costs but also raised revenues more than the increase in costs. On the other hand, Maudos and Pastor (2003) report a rise in cost efficiency and fall in profit efficiency in the Spanish banking sector. This finding is attributed to 
increasing competitive pressure in the Spanish banking sector. Cebenoyan, Cooperman and Register (2000) find a rise in cost efficiency but no significant rise in profit efficiency of thrift institutions in USA. They assert that this is an expected result given that managers have greater control over internal operations than over market conditions.

Turning to the Indian evidence, while Kumbhakar and Sarkar (2003b) report that cost efficiency has increased during 1986 to 2000, in this paper we find that profit efficiency has declined during this period and after. In fact, this is in line with the results of Koeva (2003) who, using regression analysis with financial variables of Indian banks, concluded that during the period 1992 to 2001, both intermediation costs and profitability have come down. Our results of declining profit efficiency are also in line with those of Maudos and Pastor (2001) for Japanese banks and Maudos and Pastor (2003) for Spanish banks.

As regards ownership, Kumbhakar and Sarkar (2003b) concluded that private banks are more cost efficient than public banks. However we find public banks to be more profit efficient than private banks prior to deregulation and no significant difference in the efficiencies after deregulation. New private banks, starting from low levels of profit efficiency, demonstrated rapid growth and foreign banks exhibited the lowest profit efficiency. ${ }^{22}$

Comparison of our profit productivity results with existing evidence on TFP and cost efficiency confirms the 'quality hypothesis' i.e. conflicting performances of banks in terms of cost and profit based measures. Kumbhakar and Sarkar (2003a) reported a rise in TFP (based on the cost function) over the period 1986 to 1997. They concluded that private banks had a higher level of TFP as compared with public banks. On the other 
hand, our results reveal that profit productivity has declined for all bank groups over the period under study. Foreign banks have performed the best in terms of profit productivity, ahead of public banks that in turn did better than private banks at least in the prederegulation period.

In sum, the trend and rankings get reversed to a large extent, when we compare performance of Indian banks in terms of cost and profit based measures. While in a developed and completely deregulated banking industry like in the USA, profit productivity has increased and cost productivity has declined due to banks investing heavily in improving quality (Berger and Mester, 2003), it is not surprising to find that in a deregulating system such as in India, cost performance improved due to reduction in intermediation costs while profit performance declined due to the effect of competition.

\section{Conclusion}

This paper studied efficiency and productivity of scheduled commercial banks in India during the period 1986 to 2005 using a stochastic (alternative) profit frontier. Stochastic Frontier Analysis gave us estimates of inefficiency and its determinants. Then, using the parameter and efficiency estimates from the frontier, a measure of profit productivity and its components were computed. We observed that there are profit inefficiencies in Indian banking and profit efficiency as well as profit productivity decreased over time. Although public banks had higher profit efficiency and profit productivity than private banks in the pre-deregulation period, the difference was insignificant after deregulation. Foreign banks outperformed all other bank groups in terms of profit productivity as well as its components. We interpreted the fall in profit efficiency and profit productivity over time 
as a consequence of increased competition in the industry. In this sense, the deregulation policy seems to have achieved the desired results of infusing competition in the banking industry. This should encourage the regulator to remove the remaining policy hindrances to entry and encourage greater competition. Therefore, the recent drawing of a road-map for foreign bank entry especially in light of WTO commitments augurs well for the performance of Indian banking.

The adoption of a profit maximization hypothesis in the paper may be questioned on the grounds that in reality some banks may maximize profits while others may minimize costs. In the absence of a mixing model that can incorporate both hypotheses simultaneously, we have tried to complement the existing cost based evidence with our results based on a profit maximization hypothesis. Admittedly, it would be even more interesting to study performance in a framework where banks with different objectives can be identified and the difference accounted for in the performance measurement. We leave this for our future research.

\section{Acknowledgements:}

I would like to thank an anonymous referee for useful comments. I gratefully acknowledge the comments and help received from Subrata Sarkar, Jayati Sarkar, Bibhas

Saha and Padmini Dasgupta. The remaining errors, if any, are my responsibility. 


\section{Footnotes:}

1. Berger and Humphrey (1997) documented a country-wise and methodology-wise review of studies on bank efficiency. More recently, Alam (2001) and Berger and Mester (2003) provided updated reviews.

2. To cite a few, Bhattacharyya, Bhattacharyya and Kumbhakar (1997) estimated TFP growth till 1991; Bhattacharyya, Lovell and Sahay (1997) examined efficiency till 1992; Saha and Ravisankar (2000) studied performance from 1992 to 1995; Sathye (2003) analyzed performance only for 1998.

3. Sarkar, Sarkar and Bhaumik (1998) examined financial ratios for 1994 and 1995.

4. Adoption of technology in the form of computerization, ATMs, smart cards etc. is expected to have saved costs for Indian banks.

5. The other frontier methodology is Data Envelopment Analysis which is a nonparametric technique that does not allow for the error which is expected to be present in banking data.

6. Kumbhakar (2006) suggests that duality results are not applicable in case of the alternative profit function and hence the corresponding profit efficiency cannot be related to technical inefficiency based on production technology. However it is still possible to estimate profit loss due to technical inefficiency or what is referred to as profit inefficiency.

7. Berger and Mester (1997) cited four cases when alternative profit maximization may be a preferred approach. These are when (i) there are unmeasured changes in the quality of output and banks receive higher revenues that compensate for their extra costs of producing high quality output ('quality hypothesis'); (ii) output is 
not variable; (iii) banks have some market power over the prices of their outputs; and (iv) output prices are difficult to measure.

8. Most studies on Indian banks have used this approach (see Bhattacharyya, Bhattacharyya and Kumbhakar, 1997; Kumbhakar and Sarkar, 2003a, 2003b). The value added approach also appears to be intuitively more appropriate for Indian banks for whom deposit mobilization is a key objective. Moreover, considering deposits as output takes into account the quality of services provided by a bank.

9. Most of the Indian studies in banking have employed the number of branches as an output variable (Subrahmanyam, 1993; Kumbhakar and Sarkar, 2003a, 2003b; Sensarma, 2006).

10. Note that to handle negative values, the dependent variable is taken as $\ln [\pi+$ $\left.|\pi|^{\min }+1\right]$, where $|\pi|^{\min }$ indicates the absolute value of the minimum value of over all banks. Thus, the constant $|\pi|^{\min }+1$ is added to every firm's profit so that the natural log is taken of a positive number, since minimum profits are typically negative. Thus for the firm with the lowest value of $\pi$, the dependent variable will be $\ln [1]=0$.

11. In our set of 83 banks, none of the foreign banks that entered the industry after entry deregulation could be included because of considerations of data availability.

12. According to Berger and Mester (2003), while this normalization not always necessary for the alternative profit function, but it is done to enable comparison with results from studies based on cost frontier. In fact, this approach has been 
followed by other studies that estimate the alternative profit function (Casu and Girardone, 2004; Williams and Gardener, 2003).

13. The year 1993 was selected as the deregulation year because it yielded the maximum value of likelihood function compared to the other years and also the plot of inefficiencies without any deregulation dummy showed the sharpest kink at 1993. This is expected because implementation of the recommendations of the first Narasimham Committee started in January 1992 (Kumbhakar and Sarkar, 2003b).

14. The only other sector is foreign, which becomes the base for interpreting the ownership dummies.

15. Weighted means do not change the results qualitatively.

16. Results from the t-tests are not reported to save space. These results are consistent with the relative values of the group dummy coefficients in the reduced inefficiency model.

17. This indicates that while public banks have always been the bigger banks, but their private counterparts are also gradually expanding in size over the years.

18. Higher inefficiency growth would get reflected in lower productivity; hence the second term has a negative sign in the productivity decomposition expression.

19. In this sense, this component has been referred to as the contribution of change in best practice by Berger and Mester (2003). However we follow the terminology of Kumbhakar and Lovell (2000) and use the term 'technical progress'.

20. Since the initial value of the productivity indices are set at 100 for all groups, here we miss out the difference in their initial levels which we were able to analyze 
from the efficiency estimates. However, here the indices can suggest, based on the growth rates of each component of productivity, how the bank groups corrected or worsened their performance.

21. The results with the base of all groups set at 1996 are not reported to save space.

22. Kumbhakar and Sarkar (2003a, b) did not have new private or foreign banks in their data sets. 


\section{References:}

1. Alam, Ila M. Semenick (2001) A Non-Parametric Approach For Assessing Productivity Dynamics Of Large Banks, Journal of Money, Credit, and Banking, 33, 121-139.

2. Battese, George E. and Coelli, Tim J. (1995) A Model for Technical Inefficiency Effects in a Stochastic Frontier Production Function for Panel Data, Empirical Economics, 20(2), 325-332.

3. Battese, George E. and Corra, Greg S. (1977) Estimation of a Production Frontier Model: With Application to the Pastoral Zone of Eastern Australia, Australian Journal of Agricultural Economics, 21(3), 169-179.

4. Berg, Sigbjorn Atle, Forsund, Finn R., Hjalmarsson, Lennart and Suominen, Matti (1993) Banking Efficiency in the Nordic Countries, Journal of Banking and Finance, 17, 371-388.

5. Berger, Allen N. and Humphrey, David B. (1997) Efficiency of Financial Institutions: International Survey and Directions for Future Research, European Journal of Operations Research, 98, 175-212.

6. Berger, Allen N. and Mester, Loretta J. (1997) Inside the Black Box: What Explains Differences in the Efficiencies of Financial Institutions? Journal of Banking and Finance, 21, 895-947.

7. Berger, Allen N. and Mester, Loretta J. (2003) Explaining the Dramatic Changes in Performance of US Banks: Technological Change, Deregulation, and Dynamic Changes in Competition, Journal of Financial Intermediation, 12, 57-95. 
8. Bhattacharyya, Anjana, Bhattacharyya, Arunava and Kumbhakar, Subal C. (1997) Changes in Economic Regime and Productivity Growth: A Study of Indian Public Sector Banks, Journal of Comparative Economics, 25(2), 196-219.

9. Bhattacharyya, A., Lovell, C. A. Knox and Sahay, Pankaj (1997) The Impact of Liberalization on the Productive Efficiency of Indian Commercial Banks. European Journal of Operational Research, 98, 332-345.

10. Bhaumik, Sumon Kumar and Dimova, Ralitza (2004) How Important is Ownership in a Market with Level Playing Field? The Indian Banking Sector Revisited, Journal of Comparative Economics, 32(1), 165-180.

11. Casu, Barbara and Girardone, Claudia (2004) Financial Conglomeration: Efficiency, Productivity and Strategic Drive, Applied Financial Economics, 14(10), 687-696.

12. Cebenoyan, A. Sinan and Cooperman, Elizabeth S. and Register, Charles A. (2000) Managerial Stock Ownership As A Corporate Control Device: When Is Enough, Enough? New York University Working Paper.

13. Chen, Tser-Yieth (2001) An Estimation of X-inefficiency in Taiwan's Banks, Applied Financial Economics, 11(3), 237-242.

14. Coelli, Tim J. and Battese, George E. (1996) Identification of Factors Which Influence the Technical Inefficiency of Indian Farmers, Australian Journal of Agricultural Economics, 40(2), 103-128.

15. Gilbert, R. Alton and Wilson, Paul W. (1998) Effects of Deregulation on the Productivity of Korean Banks, Journal of Economics and Business, 50(2), 133155. 
16. Grifell-Tatje, Emili and Lovell, C. A. Knox (1996) Deregulation and Productivity Decline: The Case of Spanish Savings Banks, European Economic Review, 40, 1281-1303.

17. Humphrey, David B., and Pulley, Lawrence B. (1997) Banks' Responses to Deregulation: Profits, Technology, and Efficiency, Journal of Money, Credit, and Banking, 29(1), 73-93.

18. Kasman, Adnan and Yildirim, Canan (2006) Cost and Profit Efficiencies in Transition Banking: The Case of the New EU Members, Applied Economics, 38(9), 1079-1090.

19. Kodde, David A. and Palm, Franz C. (1986) Wald Criteria for Jointly Testing Equality and Inequality Restrictions, Econometrica, 54(5), 1243-1248.

20. Koeva, Petya (2003) The Performance of Indian Banks during Financial Liberalization, International Monetary Fund Working Paper.

21. Kumbhakar, Subal C. (2006) Productivity and Efficiency Measurement Using Parametric Econometric Methods, Empirical Economics, 31(3), 799-799.

22. Kumbhakar, Subal C. and Lovell, C. A. Knox (2000) Stochastic Frontier Analysis, Cambridge, New York and Melbourne: Cambridge University Press,

23. Kumbhakar, Subal C., Lozano-Vivas, A., Lovell, C. A. K., Iftekhar, H. (2001) The Effects of Deregulation on the Performance of Financial Institutions: The case of Spanish Savings Banks, Journal of Money, Credit and Banking, 33(1), $101-120$. 
24. Kumbhakar, Subal C. and Sarkar, Subrata (2003a) Deregulation, Ownership, and Productivity Growth: Evidence from Indian Banks, Journal of Money, Credit, and Banking, 35(3), 403-424.

25. Kumbhakar, S. C. and Sarkar, Subrata (2003b) Deregulation, Ownership and Efficiency Change in Indian Banking: An Application of Stochastic Frontier Analysis, Arthaniti, 2(1-2), 1-26.

26. Lovano-Vivas, Ana (1998) Efficiency and Technical Change for Spanish Banks, Applied Financial Economics, 8(3), 289-300.

27. Maudos, Joaquin and Pastor, Jose Manuel (2001) Cost and Profit Efficiency in Banking: An International Comparison of Europe, Japan and the USA, Applied Economics Letters, 8(6), 383-387.

28. Maudos, Joaquin and Pastor, Jose Manuel (2003) Cost and Profit Efficiency in the Spanish Banking Sector (1985-1996): A Non-parametric Approach, Applied Financial Economics, 13(1), 1-12.

29. Mendes, Victor and Rebelo, Joao (1999) Productive Efficiency, Technological Change and Productivity in Portuguese Banking, Applied Financial Economics, 9(5), 513-521.

30. Pastor, Jose M. and Serrano, Lorenzo (2005) Efficiency, endogenous and exogenous credit risk in the banking systems of the Euro area, Applied Financial Economics, 15(9), 631-649.

31. Saha, A.and Ravisankar, T. S. (2000) Rating of Indian Commercial Banks: A DEA Approach, European Journal of Operational Research, 124, 187-203. 
32. Sarkar, Jayati, Sarkar, Subrata, and Bhaumik, Sumon Kumar (1998) Does Ownership Always Matter? Evidence from the Indian Banking Industry, Journal of Comparative Economics, 26(2), 262-281.

33. Sathye, M. (2003) Efficiency of Banks in a Developing Economy: The Case of India, European Journal of Operational Research, 148, 662-671.

34. Sensarma, R. (2006) Are Foreign Banks Always the Best? Comparison of StateOwned, Private and Foreign Banks in India, Economic Modelling, 23(4), 717-735.

35. Shanmugam, Kumarapalayam R. and Das, Abhiman (2004) Efficiency of Indian Commercial Banks During the Reform Period, Applied Financial Economics, 14(9), 681-686.

36. Subrahmanyam, Ganti (1993) Productivity Growth in India's Public Sector Banks, 1970 -1989, Journal of Quantitative Economics, 9, 209-223.

37. Williams, Jonathan and Gardener, Edward P. M. (2003) The Efficiency of European Regional Banking, Regional Studies, 37(4), 321-330.

38. Yildirim, H. Semih and Philippatos, George C. (2002) Efficiency of Banks: Recent Evidence from the Transition Economies of Europe: 1993-2000, University of Saskatchewan Working Paper. 
Table 1: Key Indicators Of Indian Banking: Group-Wise Means

\begin{tabular}{|c|c|c|c|c|c|}
\hline Variable & 1986 & 1990 & 1996 & 2000 & 2005 \\
\hline Profits (Rs. millions) & & & & & \\
\hline Public banks & 0.884 & 1.709 & -1.142 & 12.377 & 30.301 \\
\hline Private banks & 0.062 & 0.143 & 1.292 & 1.808 & 1.076 \\
\hline Foreign banks & 0.421 & 1.399 & 2.520 & 1.483 & 20.587 \\
\hline New private banks & & & 1.537 & 4.643 & 35.034 \\
\hline Deposits (Rs. millions) & & & & & \\
\hline Public banks & 703.430 & 1015.920 & 1206.230 & 1709.140 & 3004.280 \\
\hline Private banks & 37.020 & 50.570 & 106.930 & 181.890 & 393.850 \\
\hline Foreign banks & 33.860 & 65.890 & 110.560 & 76.760 & 4.040 \\
\hline New private banks & & & 54.970 & 381.390 & 1994.920 \\
\hline Investments (Rs. millions) & & & & & \\
\hline Public banks & 209.985 & 342.145 & 502.059 & 807.107 & 1336.370 \\
\hline Private banks & 11.210 & 16.617 & 35.478 & 74.308 & 152.140 \\
\hline Foreign banks & 10.018 & 20.259 & 40.178 & 46.162 & 375.930 \\
\hline New private banks & & & 16.194 & 192.067 & 977.660 \\
\hline Advances (Rs. Millions) & & & & & \\
\hline Public banks & 420.582 & 41.109 & 640.556 & 852.360 & 1619.220 \\
\hline Private banks & 20.105 & 649.139 & 61.714 & 91.460 & 231.550 \\
\hline Foreign banks & 24.680 & 28.873 & 80.051 & 55.425 & 695.010 \\
\hline New private banks & & & 45.278 & 181.013 & 1554.250 \\
\hline Branches & & & & & \\
\hline Public banks & 13133.300 & 15152.600 & 16374.400 & 17142.600 & 18082.600 \\
\hline Private banks & 1590.500 & 1642.200 & 1816.100 & 1919.200 & 2722.500 \\
\hline Foreign banks & 80.000 & 71.100 & 66.500 & 42.400 & 277.500 \\
\hline New private banks & & & 91.100 & 575.000 & 2836.000 \\
\hline Employees & & & & & \\
\hline Public banks & 289768.500 & 315703.700 & 331440.400 & 323766.700 & 276389.300 \\
\hline Private banks & 19791.400 & 21992.600 & 24293.000 & 24718.300 & 30971.300 \\
\hline Foreign banks & 6616.300 & 6443.200 & 5803.000 & 3230.200 & 21650.000 \\
\hline New private banks & & & 793.875 & 7938.800 & 70864.000 \\
\hline Fixed Assets & & & & & \\
\hline Public banks & 4.750 & 6.427 & 20.333 & 24.258 & 25.129 \\
\hline Private banks & 0.306 & 0.360 & 3.321 & 4.126 & 5.408 \\
\hline Foreign banks & 0.619 & 1.101 & 5.435 & 3.743 & 18.049 \\
\hline New private banks & & & 3.732 & 17.843 & 61.900 \\
\hline
\end{tabular}

Note: . for new private banks prior to their entry. All rupee figures are at 1993-1994 prices. The exchange rate in 2005 was USD1=Rs.44.10. 
Table 2: Maximum Likelihood Estimates of the Stochastic Profit Frontier based on Panel Data for Banks for Years 1986 to 2005

\begin{tabular}{|c|c|c|c|c|c|}
\hline Beta & Estimate & t-ratio & Delta & Estimate & t-ratio \\
\hline CONST & 1.451 & 8.662 & CONST & 1.415 & 8.780 \\
\hline FD & 0.669 & 5.124 & & 0.017 & 0.772 \\
\hline SD & -0.449 & -6.778 & DEREG & -0.562 & -2.207 \\
\hline$C D$ & -0.232 & -2.782 & SIZE & -0.789 & -28.956 \\
\hline INV & 0.150 & 1.262 & PUB & -1.804 & -10.841 \\
\hline ADV & -0.254 & -2.012 & PVT & -2.789 & -10.86 \\
\hline B & -0.111 & -1.765 & NEWPVT & -1.683 & -2.145 \\
\hline W & -1.282 & -38.257 & DEREG ${ }^{*} T$ & 0.073 & 2.714 \\
\hline $\mathrm{T}$ & 0.101 & 6.480 & DEREG*PUB & -1.571 & -5.428 \\
\hline FD2 & -0.024 & -1.221 & DEREG ${ }^{*} P V T$ & -2.226 & -4.58 \\
\hline SD2 & -0.020 & -3.177 & DEREG*NEWPVT & -1.683 & -2.145 \\
\hline CD2 & 0.001 & 0.003 & DEREG*T*PUB & 0.153 & 6.614 \\
\hline INV2 & -0.025 & -1.961 & DEREG ${ }^{*} T * P V T$ & 0.178 & 5.254 \\
\hline ADV2 & -0.030 & -1.567 & DEREG* ${ }^{*}{ }^{*} N E W P V T$ & 0.021 & 0.451 \\
\hline B2 & -0.030 & -4.554 & & & \\
\hline W2 & -0.125 & -51.279 & & & \\
\hline T2 & 0.001 & 0.788 & & & \\
\hline FD*SD & -0.003 & -0.213 & & & \\
\hline $\mathrm{FD} * \mathrm{CD}$ & 0.019 & 0.848 & Sigma-squared & 0.483 & 21.217 \\
\hline FD*INV & 0.050 & 1.608 & Gamma & 0.936 & 140.547 \\
\hline $\begin{array}{l}F D^{*} A D V \\
F D^{*} R\end{array}$ & $\begin{array}{r}0.026 \\
-0.032\end{array}$ & $\begin{array}{r}0.835 \\
-1.928\end{array}$ & & & \\
\hline $\mathrm{FD}{ }^{\star} \mathrm{B}$ & -0.032 & -1.928 & Log Likelihood & -365.684 & \\
\hline$F D^{*} \mathrm{~W}$ & 0.064 & 5.108 & LR Test for $\gamma=\delta_{i}=0, \forall \mathrm{i}$ & $705.93^{*}$ & \\
\hline$F D^{\star} T$ & -0.003 & -0.676 & LR Test for $\delta_{i}=0, \forall \mathrm{i}$ & $625.12^{*}$ & \\
\hline$S D^{*} \mathrm{CD}$ & 0.005 & 0.517 & & & \\
\hline SD*INV & 0.013 & 0.848 & & & \\
\hline$S D^{\star} A D V$ & 0.045 & 3.599 & & & \\
\hline$S D^{*} B$ & -0.018 & -1.623 & & & \\
\hline$S D^{*} W$ & -0.037 & -7.295 & & & \\
\hline$S D^{*} T$ & 0.008 & 2.733 & & & \\
\hline CD*INV & -0.044 & -1.767 & & & \\
\hline$C D * A D V$ & -0.088 & -3.846 & & & \\
\hline$C D * B$ & 0.083 & 6.347 & & & \\
\hline$C D^{*} W$ & 0.010 & 1.649 & & & \\
\hline$C D * T$ & 0.009 & 2.652 & & & \\
\hline INV*ADV & 0.056 & 2.145 & & & \\
\hline$I N V^{*} B$ & 0.046 & 2.884 & & & \\
\hline INV*W & 0.041 & 3.492 & & & \\
\hline $\mathrm{INV}{ }^{*} \mathrm{~T}$ & -0.015 & -2.811 & & & \\
\hline$A D{ }^{*} B$ & -0.004 & -0.228 & & & \\
\hline$A D V * W$ & -0.034 & -3.309 & & & \\
\hline$A D V * T$ & -0.004 & -0.684 & & & \\
\hline$B^{*} W$ & -0.048 & -9.235 & & & \\
\hline$B^{*} T$ & 0.001 & 0.179 & Number of Banks & 83 & \\
\hline$W^{*} T$ & 0.013 & 9.702 & Number of Observations & 1362 & \\
\hline
\end{tabular}

Notes: FD = Fixed Deposits, SD = Saving Deposits, CD = Current Deposits, INV = Investments, ADV = Loans and Advances, $\mathrm{B}=$ Number of branches, $\mathrm{W}=$ Wage-rental ratio, $\mathrm{T}=$ Time trend $\left(\right.$ Year), ${ }^{*}$ denotes significance (Kodde and Palm, 1986) 
Table 3: Estimated Reduced Profit Inefficiency Model

\begin{tabular}{|l|r|r|}
\hline Delta & Estimate & \multicolumn{1}{l|}{-ratio } \\
\hline Trend behaviour & & \\
CONST & -3.608 & -17.015 \\
T & 0.398 & 18.568 \\
\hline Deregulation & & \\
effect & & \\
CONST & -3.661 & -2.291 \\
T & 0.396 & 18.357 \\
DEREG*T & 0.059 & 0.631 \\
\hline Ownership effect & & \\
CONST & 1.059 & 11.653 \\
PUB & -4.344 & -7.815 \\
PVT & -3.827 & -8.898 \\
NEWPVT & -1.421 & -8.539 \\
\hline
\end{tabular}


Table 4: Mean Profit Efficiency by Bank Groups

\begin{tabular}{|r|r|r|r|r|}
\hline Year & \multicolumn{1}{|c|}{ Public } & \multicolumn{1}{|c|}{ Private } & Foreign & New Private \\
\hline 1986 & 91.15 & 85.07 & 42.40 &. \\
1987 & 91.09 & 84.91 & 42.21 &. \\
1988 & 91.83 & 86.92 & 43.93 &. \\
1989 & 84.98 & 79.91 & 39.05 &. \\
1990 & 89.88 & 85.51 & 46.11 &. \\
1991 & 90.69 & 85.79 & 49.60 &. \\
1992 & 90.92 & 86.92 & 58.03 &. \\
1993 & 87.11 & 88.11 & 61.45 &. \\
1994 & 87.87 & 91.24 & 61.63 &. \\
1995 & 91.11 & 90.76 & 59.99 &. \\
1996 & 86.76 & 88.97 & 56.45 &. \\
1997 & 89.75 & 83.87 & 43.79 & 83.55 \\
1998 & 90.13 & 86.65 & 37.67 & 82.69 \\
1999 & 88.18 & 81.90 & 37.83 & 82.91 \\
2000 & 87.59 & 86.10 & 39.83 & 91.53 \\
2001 & 77.80 & 85.83 & 36.13 & 90.29 \\
2002 & 83.32 & 83.95 & 33.98 & 89.05 \\
2003 & 82.56 & 78.05 & 39.40 & 85.47 \\
2004 & 85.58 & 82.55 & 62.75 & 90.17 \\
2005 & 84.45 & 81.07 & 64.34 & 81.49 \\
\hline
\end{tabular}

Note: for new private banks prior to their entry. 
Table 5: Indices of Productivity Components and Profit Productivity

\begin{tabular}{|r|r|r|r|r|r|r|r|r|r|}
\hline & \multicolumn{3}{|c|}{ Technical Change Component } & \multicolumn{2}{c|}{ Efficiency Component } & \multicolumn{3}{|c|}{ Profit Productivity } \\
\hline Year & Public & \multicolumn{1}{|c|}{ Private } & \multicolumn{1}{|c|}{ Foreign } & Public & Private & Foreign & Public & Private & Foreign \\
\hline 1986 & 100.00 & 100.00 & 100.00 & 100.00 & 100.00 & 100.00 & 100.00 & 100.00 & 100.00 \\
1987 & 92.12 & 99.99 & 92.11 & 90.74 & 99.48 & 90.60 & 91.22 & 99.49 & 93.69 \\
1988 & 85.00 & 100.80 & 85.73 & 82.36 & 104.18 & 86.51 & 83.31 & 101.20 & 89.97 \\
1989 & 78.47 & 93.41 & 72.87 & 74.80 & 95.68 & 71.52 & 76.24 & 91.18 & 73.23 \\
1990 & 72.50 & 98.38 & 71.20 & 67.90 & 102.10 & 69.71 & 69.78 & 104.61 & 81.51 \\
1991 & 66.96 & 99.19 & 66.34 & 61.63 & 102.47 & 63.54 & 64.09 & 111.43 & 82.12 \\
1992 & 61.95 & 99.45 & 61.56 & 55.95 & 103.80 & 58.50 & 58.87 & 135.68 & 93.30 \\
1993 & 57.35 & 94.78 & 54.10 & 50.86 & 105.42 & 54.10 & 54.22 & 144.09 & 91.71 \\
1994 & 53.14 & 95.47 & 50.52 & 46.31 & 110.22 & 51.72 & 50.09 & 153.43 & 90.66 \\
1995 & 49.18 & 99.45 & 48.86 & 42.23 & 109.64 & 46.89 & 46.16 & 149.17 & 81.03 \\
1996 & 45.54 & 93.71 & 42.42 & 38.53 & 107.66 & 41.93 & 42.50 & 134.28 & 66.53 \\
1997 & 42.18 & 97.58 & 41.05 & 35.28 & 98.10 & 38.56 & 38.97 & 144.90 & 63.55 \\
1998 & 39.12 & 97.86 & 38.18 & 32.40 & 96.73 & 35.13 & 35.70 & 130.98 & 50.16 \\
1999 & 36.31 & 95.66 & 34.58 & 29.76 & 87.67 & 31.75 & 32.72 & 126.05 & 46.76 \\
2000 & 33.75 & 94.91 & 31.87 & 27.37 & 91.09 & 30.83 & 29.94 & 115.60 & 40.10 \\
2001 & 31.40 & 83.42 & 25.79 & 25.18 & 96.50 & 30.20 & 27.44 & 118.67 & 39.53 \\
2002 & 29.23 & 89.00 & 25.74 & 23.19 & 94.16 & 26.76 & 25.13 & 109.48 & 35.81 \\
2003 & 27.26 & 87.81 & 23.66 & 21.36 & 85.11 & 23.80 & 23.01 & 120.71 & 35.98 \\
2004 & 25.70 & 91.04 & 23.15 & 19.85 & 92.18 & 24.09 & 21.35 & 94.83 & 24.38 \\
2005 & 24.23 & 89.44 & 21.17 & 18.41 & 89.71 & 22.52 & 19.78 & 95.83 & 22.92 \\
\hline
\end{tabular}


Table 6: Indices of Productivity Components and Profit Productivity for New Private Banks

\begin{tabular}{|r|r|r|r|}
\hline Year & Technical Change Component & Efficiency Component & Profit Productivity \\
\hline 1996 & 100.00 & 100.00 & 100.00 \\
1997 & 92.73 & 104.14 & 96.97 \\
1998 & 86.31 & 101.71 & 88.05 \\
1999 & 80.45 & 102.12 & 82.42 \\
2000 & 75.24 & 115.44 & 87.78 \\
2001 & 70.44 & 113.33 & 80.71 \\
2002 & 65.89 & 11.79 & 73.81 \\
2003 & 61.78 & 104.81 & 63.49 \\
2004 & 57.82 & 110.90 & 61.54 \\
2005 & 54.21 & 93.96 & 57.98 \\
\hline
\end{tabular}

